\title{
Industry 4.0: current trend and future scope for further research in High Performance Manufacturing
}

\author{
Mario R. Acevedo Amaya, $\mathrm{PhD}^{1,2}$, Cesar H. Ortega-Jiménez, $\mathrm{PhD}^{1}$, Jose AD Machuca, $\mathrm{PhD}^{2}$, Rafaela Alfalla-Luque, \\ $\mathrm{PhD}^{2}$. \\ ${ }^{1}$ Universidad Nacional Autónoma de Honduras, Honduras, mario.acevedo@unah.edu.hn, cortega@unah.edu.hn \\ 33niversidad de Sevilla, España, jmachuca@us.es, alfalla@us.es
}

\begin{abstract}
The fourth industrial revolution requires that personalization processes of mass productions evolve towards flexible, interconnected, cloud production with greater automation in its machines and operations, called Industry 4.0 (14.0). However, a homogeneous I4.0 concept, infrastructure state, and other issues are still scarce, making difficult to determinate in the specialized literature, the threshold between recent manufacturing and challenges that companies had to reach competitive advantage through I4.0 inclusion. Despite becoming one of the most popular strategies for continuous improvement, many plants are struggling to turn I4.0 into a success. Therefore, this paper analyzes the current trends of Industry 4.0 in High Performance Manufacturing (HPM), aiming to consolidate the existing knowledge on both subjects, providing a starting point for academics and practitioners seeking to implement I4.0 in plants and offering suggestions for future examination. This systematic literature review aims to synthesize, organize, and structure the stock of knowledge relating to I4.0 and HPM. The results show that HPM papers do not evidence a holistic evaluation of I.40 principles and foundations. There exists in HPM literature manufacturing practices that permit evaluate technology inclusion and their performance but not their autonomy, cloud computing and network between machines, supplier, and processes. The HPM papers trends are related with issues such as adaptability, flexibility, reconfigurability, new information technologies, modularity, automation, etc. Regarding study limitations, it is necessary to study current I4.0 adoption level, technological infrastructure, and cultural factors. The practical implications are focused in the identification of manufacturing practices used in specialized literature to measure how technology inclusion increase companies' performance, proving the technological infrastructure and I4.0 maturity level. The originality of this paper converges on the presentation of some manufacturing practices applied on HPM studies which are associated with I4.0.
\end{abstract}

Keywords-- Industry 4.0, High Performance Manufacturing.

\section{INTRODUCTION}

\section{A. Industry 4.0}

Competitiveness increasingly depends on the technological revolution through interactions and interventions in organizations achieve on their supply chains, where a higher technological inclusion level gives organizations a greater competitive advantage [1]. Most competitive environments exhibit globalization characteristics and rapid technological transfer, due needed to anticipate and adapt to changing market, demanding firms must be more innovative and flexible [2]. Technology become a mediating factor to improve operations performance [3]. With internet-triggered fourth industrial revolution, also known as "Industry 4.0" (I4.0), is expected

Digital Object Identifier (DOI):

http://dx.doi.org/10.18687/LACCEI2020.1.1.303

ISBN: 978-958-52071-4-1 ISSN: 2414-6390 change in landscape industries. The companies need to rethink modeling and analysis to integrate available data [4]. Nonetheless, this is not a new topic, Osterrieder, Budde, \& Friedli (2019) establish that since 80's some authors such Shaw (1983) envisioned a future state of a completely autonomous factory by relying on advanced robotics [5]. The scope of digital transformation in manufacturing is vast and extent to which it occurs is result of several elements combination such as internet, automation, flexibility, adaptability, reconfigurability, modularity, networking, among others, designed and implemented to achieve high performance in companies [6]. Therefore, literature shows that companies must adopt a new strategy to offer more personalized products, which forces them to transform their production system (modularity, flexibility, adaptability, and agility), evolving companies' towards personalized mass production, where I4.0 it is a way to achieve a high productive level [7]. I4.0 develops when the paradigm Internet of Things (IoT) is merged with Cyber Physical Systems (CPS) idea [6] and cloud computing, with the potential of becoming global production language [8] although it is a complex technological architecture that represent a challenge to manufacturing systems [9]. I4.0 is widely used to describe the digital factory concept, where human intervention is reduced to minimum and indispensable [5]. The term I4.0 was introduced in Germany [8] and emerged for the first time in 2011 with the aim to characterizing highly digitized manufacturing processes $[5,6]$ through program called High Tech Strategy 2020, becoming a worldwide movement. In United States, it was established as "Advance Manufacturing Partnership", in China as "Made in China 2025" and in France as a program called "La Nouvelle France Industrielle" [10]. I4.0 contributes with manufacturing sector through vertical and horizontal integration, as well as, end to end engineering [11], to achieve a high-performance manufacturing across production systems automation [12].

I4.0 is similarly referenced as smart manufacturing [8], advanced manufacturing, smart factory or industry, networking manufacturing, intelligent manufacturing [13], due their capacity to have machines equipped with sensors [3], artificial intelligence and data analytics to optimize and achieve high performance manufacturing [8]. I4.0 can be defined as technical requirements that support production processes based on technology and devices autonomously, communicating with each other through interoperability, virtualization, decentralization, real time capabilities, service orientation and modularity. This implies five levels, depending of companies' technology levels (maturity level or Cyber Physical Systems 
level) [5]: (1) connection level; (2) conversion level; (3) cyber level; (4) cognition level; and (5) configuration level (intelligent production). I4.0 are measured with level and performance of: (1) Interconnection or interconnectivity (speed, mobile connection to internet), (2) Interoperability (Cyber physical systems, machines, assembly lines, sensor), (3) Enterprise (Enterprise Resource Planning, automatically linked to those of their supplier and/or customers, business to business and Government), (4) Virtualization, and (5) Buy high Cloud Computing, Services (Accounting software applications, CRM, Computing power), these allows evaluated I4.0 in two ways: I4.0 infrastructure and big data maturity [9]. Furthermore, I4.0 can be classified in seven different categories: (1) Data analysis and processing, (2) Augmented reality, (3) Cloud computing, (4) Mobile devices, (5) Internet of Thing, (6) Additive manufacturing, and (7) CPS [11]. From operational perspective, digital technologies related with I4.0, such as CPS, are proposed to reduce set up times, labor and material cost and processing times, resulting in high performance manufacturing [10].

CPS is the core foundation of I4.0, whose notation can be traced back to 2006, which function consists in various embedded devices that are networked to sense, monitor and actuate physical elements, measured through CPS maturity [8]. CPS stand for one of the key concepts within I4.0 to achieve manufacturing systems connectivity [4] through different software systems and data communication streams that need to be integrated and connected to intelligently control whole manufacturing chain [4]. CPS is related to physical (Numeric Control, CNC, CAD, Manufacturing Systems, CIM, IMS, Robotics, HMS, Tracking and racing, product service systems grid manufacturing, cloud services) and virtual world (computers, microprocessors, computer graphics, computer networks, databases, Machine learning, AI, Computer vision, Internet, MAS, Wireless, sensor, embedded systems, semantic web, grid computer, cloud computing) [13]. CPS applied directly in production processes is it called Cyber physical production systems (CPPS) which their fundamental question is how to explore the relation of autonomy, cooperation, optimization and responsiveness along different manufacturing processes and practices to achieve high performance. CPPS consist of autonomous and cooperative elements and subsystems connected across all levels of production, with three main characteristic [13]: (1) Intelligence (smartness), (2) Connectedness and (3) responsiveness, evaluated through: (1) Key technologies, (2) Adopted technologies, (3) Expected benefits, (4) Internal barriers, (5) External barriers, and (6) Industry policy.

All these variables and indicators are present across different manufacturing practices; Product design, Production planning, Production engineering, Producing products and services, Lean, Technology management, Supply chain management, Operations strategy Quality management [12], Value stream mapping, 5s, Kainzen, Just in time (lean manufacturing along industry 4.0), Pull flow, Machine learning and separation, Human resource and teamwork [11, 6]. CPPS are evaluated at technological level across to [10]: (1) CAD/CAM, (2) Integrated engineering system, (3) Digital automation with sensors, (4) flexible manufacturing lines, (5) MES and SCADA System, (6) Big Data, (7) Digital product service, (8) Additive manufacturing and (9) Cloud services.

However, a challenge aspect of I4.0 to required priority attention is I4.0 security, not only in data level, but also along their infrastructure. Thus, transformation of the industrial era carries with a very high probability of different new risks occurring. Hence, the integration of I4.0 and key infrastructure for the digitalization of manufacturing creates a new potential danger. The risks from the IT world may affect the industrial manufacturing process and we may find new potential manufacturing industrial risks, among them: cyber-attack, malware, spyware, loss of data integrity or problems with the availability of information, being a key subject in the future research [14]. Also, exists many challenges for understanding, definition, and evaluation of I4.0 effects on companies' competitive performance. An I4.0-challenge is the standardization and continuous research through programs dedicated to measuring high performance. Literature shows that existed some standardization effort from different programs around the world. One is the Reference Architecture Model of Industry 4.0 (RAMI) [4] and the second one is the Industrial Internet Reference Architecture (IIRA) [8]. But, standardization and I4.0 implementation processes faces several challenges [7, 11]: (1) Risk of security breaches including infrastructure security of I4.0, (2) Low maturity level of preferred technology, (3) Inequality, (4) Disruption of existing jobs, (5) Lack of standards, (6) Regulation and form of certification, (7) Lack of infrastructure, (8) Digital skills, (9) Challenges in ensuring data quality, (10) Lack of internal digital culture and training, (11) Ineffective change management, and (12) Lack of a digital strategy alongside resource scarcity.

Other I4.0 topics that are challenges and future scope are: 1. Lack of consistent knowledge about how I4.0 revolution is going to affect industries future [11]; 2. Some organizations do not consider I4.0 revolution in their own culture [12]; 3 . Most articles focus on single case studies, still exist niches (supply chain and manufacturing performance)[4]; 4. Advanced automation, virtualization and flexibilization are frontiers regarding I4.0 implementation complexity [9]. 5. The level of I4.0 implementation that required to generate competitive advantages through I.40 levels maturity [9]. Another challenge is for managers who are starting new factories because should think and study about I4.0 before defining manufacturing layout, so that this may not be a future restriction in I4.0 implementation [9]. I4.0 has high potential [11] allowing companies to increase productivity [10], evidence of America Society for Quality (ASO) survey support that I.40 inclusion along manufacturing process increase their performance [12]. Further organizations that implemented smart manufacturing stated they have experienced increased efficiency, $49 \%$ 
experienced fewer product defects, and $45 \%$ achieved increased customer satisfaction [12].

\section{B. Research problem}

Even with the progress shown, there are still a few studies of I4.0 derived from programs that evaluate constantly their contribution to high performance. This is currently the case of HPM project, that when we assessed literature related to High Performance Manufacturing (HPM), we found that in this program only evaluates isolated aspects of I4.0 through practices related to internet, automation, flexibility and adaptability around competitive performance and not as a scale that determine infrastructure and maturity levels of I4.0 [5].

HPM project arises with the purpose of study manufacturing practices that lead to high performance for companies [15] leaving aside I4.0 challenges. Literature on HPM often highlights the importance to update enquiry lines and be at the forefront as industry revolutionizes, especially of communication and information management, but there is a lack of study dealing specially with these aspects due to its recent appearance and push in companies [16]. HPM Project had the first Round of this Project started in 1989 with two countries (USA and Japan) and new countries were added every Round until current (4th round). Last data collection involved various teams of academics from several universities in fifteen countries in Europe, America and Asia [17].

HPM project considers operations programs such as Lean Manufacturing, Technology Management (TM), Manufacturing Strategy (MS), Total Quality Management (TQM), Human Resources, Information Systems and others, with the hypothesis that roll out of these practices should lead to superior performance. However, superior performance requires alignment of manufacturing function, technology, and business strategy. HPM project can be related with I4.0 through advanced technology, that is the foundation of I4.0, where many different technologies are already used in manufacturing, but new solutions related with I4.0 are needed to transform production and increase company's performance, with integrated processes and automated production lines that will lead to higher performance and greater efficiency [18].

Hence, HPM project must make an effective integration between manufacturing practices with new technologies applications due that are critical in I4.0. Nonetheless, it is important the continuous inquiry because one of the important issues surrounding I4.0 is the fact that existing equipment is not capable of communicating with newly deployed technology. HPM project challenges are not only an operational level, are so many questions at technical and strategic level that are related with infrastructure, scalability, environment, data science, data analytic, block chain, security, resilience, integration of internet of things and autonomy [8]. Consequently, HPM project require the measurement of I4.0, to convert the regular machines to self-aware and self-learning machines to improve their overall performance [19].
Despite of foregoing importance, in current specialized literature there is no universal definition and standard about what constitutes an industrial revolution. There are still few efforts at governmental, academic, and business levels to systematize the state of art of the new industrial revolution and specifically those related to high-performance manufacturing project [20]. In addition, Castelo-Branco, Cruz-Jesus, \& Oliveira, (2019) argument that industry 4.0 focuses its importance on adoption of techniques and processes allowed to gain competitive advantage in domestic and global markets, achieving high performance manufacturing. As well, this paper recognizes difficulties on how manufacturing sector is adopting I4.0, since it continues to be a challenge. At the same time, Sony \& Naik (2018) details that industry 4.0 is the present tendency of automation and data exchange, but still lacks of a common understanding in terms of I4.0 evaluation; in this sense, it is necessary to systematically study literature to identify the key factors for assessing I4.0 readiness for organizations. Therefore, the different programs such as HPM, need to establish a way that guarantees the establishment of future research needs that contribute to the comprehensive understanding of I4.0 operation. Considering the previous literature, this paper aims the development of the following research questions:

RQ1. What is the trend of HPM project research related to industry 4.0, according to the published empirical studies? RQ2. What are the variables that have been used in HPM project research to evaluate technology inclusion, internet of things, cloud computing, cyber physical systems, adaptability, flexibility, time, performance and integration such as previous elements of industry 4.0 in manufacturing? RQ3. What is the future scope for further investigation of HPM project related with industry 4.0 ?

Given this, we consider an updated systematic literature review on both HPM and I4.0 are needed. As study in I4.0 is still in development, with fragmented and diverse studies, it would benefit significantly from a study aimed at understanding and reorganising available knowledge around HPM and I4.0. This review also makes an important methodological contribution by applying elements of systematic reviews originating from so-called hard sciences to management studies field, where there is few systematic studies and concepts are often poorly operationalised, often meaning a failure to provide enough help to plants in their efforts to deploy I4.0 in HPM contexts. The focus of this inquiry was to consolidate existing knowledge on both subjects, providing a starting point for investigators and practitioners seeking to implement I4.0 in plants and offering suggestions for future investigation. At the same time, this will have managerial implications, helping plants that want implementing I4.0 along SCM to ensure they have right path to achieve HPM. The reminder of this paper is organized as follows: section I presents a review of studies related to I4.0 and High-Performance Manufacturing. Methodology is described in Section II. Section III analyzes the results and comments on main findings. Finally, section IV 
present conclusions that bring the paper to a close with the article's discussions, limitations, final considerations, and conclusions.

\section{RESEARCH METHODOLOGY}

Literature review is essential for the academy, which can take two forms. First, serve as a background for empirical study and stand-alone piece. Second, allows to know the state of literature, identifying the gaps to make new contributions, test hypotheses and generate new theories [21]. In this meaning, the methodology is focused on Kitchenham and Charters (2007) inquiry, which consists on the following sections: Search strategy, Search Criteria, Data bases and searches, Inclusion and exclusion criteria, Study search, selection, data extraction and synthesis [22]. For the source's selection, a reviewed of sources where the major part of HPM project authors publish about I4.0.

TABLE I

SEARCH SOURCE

\begin{tabular}{|l|l|}
\hline Electronic databases & Scopus \\
\hline & Web of science \\
\hline & Elsevier/Science direct \\
\hline Searched items & Journals \\
\hline Search applied on & $\begin{array}{l}\text { Full text review - to avoid losing those } \\
\text { documents that do not express the } \\
\text { keywords in title and abstract }\end{array}$ \\
\hline Language & English \\
\hline Publication period & From 2015 to 2019 \\
\hline
\end{tabular}

A. Search strategy

To develop the literature review we used systematic literature review methodology [21]. The information collected comes from electronic databases, specifically from scientific articles related to search chains. Table I shows electronic databases, searched items, search applied on, language and publication period. We only select the source where HPM authors were published their research, excluding proceeding and other journals where not exist publications of HPM project. Studies collected were analyzed and reviewed to identify contributions, search criteria, new references, representative authors, and other investigation dealings. The extraction of enquiry's was carried out in compliance with inclusion and exclusion criteria along three review rounds [23].

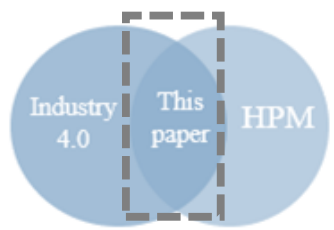

Fig. 1. The position of this paper regarding research within HPM and Industry 4.0.

First, to extract all information related to search strings, sorted by relevance and number of citations. Second, based on the analysis of relationship between keywords directly and search strings. Third round were to select documents that, due to their contribution, quality, validity, representativeness and contribution, answer research questions.

\section{B. Search criteria}

Search criteria used in this systematic literature review are derivate of main components of I4.0: SC1: ("adaptability") and ("HPM"), SC2: ("reconfigurability") and ("HPM"), SC3: ("customization") and ("HPM"), SC4: ("information systems" ) and ("HPM"), SC5: ("integrability") AND ("HPM"), SC6: ("internet of things") and ("HPM"), SC7: ("internet") and ("HPM") and ("HPM project") and ("Cloud computing").

C. Data bases and searchers, inclusion, and exclusion criteria

Databases consulted correspond to the following electronic sources: ISI Web of Science, Emerald / Science direct, Scopus. Search objects are articles of scientific journals considered full paper, and that are relevant to investigation aims. The language used in analyzed documents were English. The systematic literature review was developed based on the following inclusion criteria: (IC1) Double blind review articles in specialist journal, (IC2) Written and published in English, (IC3) Relevant terms defined in the introduction of this document, with empirical evidence that contributes to explanation of the aim of this paper. (IC4)

The papers must have been published from January 2015 to November 2019. Exclusion criteria considered for this systematic literature review were: (EC1) papers contribution does not allow understanding industries 4.0 and do not allow establishment of scales that assess company's performance, (EC2) papers that are not directly focused on the keywords, (EC4) Excluded from the search: opinions, points of view, discussions, annotations, editorials, comments, tutorials, prefaces and experiences, as well as those presentations in slide format.

D. Data extraction and synthesis, study search, selection, data extraction and synthesis

The results of search chains generated a total of 1,156 papers related with I4.0 published in conference proceeding, and journals, which were refined in three rounds. The filtering process is shown in Table II.

TABLE II

IDENTIFIED STUDIES DURING THE THREE ROUNDS OF SYSTEMATIC SEARCH (I: INCLUDED / E: EXCLUDED)

\begin{tabular}{|l|c|c|c|c|c|c|c|}
\hline \multirow{2}{*}{ DB } & \multirow{2}{*}{ Total } & \multicolumn{2}{|c|}{ Round 1} & \multicolumn{2}{|c|}{ Round } & \multicolumn{2}{|c|}{ Round } \\
\cline { 3 - 8 } & & $I$ & $E$ & $I$ & $E$ & $I$ & $E$ \\
\hline Scopus & 434 & 54 & 380 & 37 & 17 & 8 & 29 \\
\hline Web of science & 222 & 56 & 166 & 33 & 23 & 3 & 30 \\
\hline $\begin{array}{l}\text { Elsevier/Science } \\
\text { direct }\end{array}$ & 500 & 17 & 483 & 12 & 5 & 5 & 7 \\
\hline
\end{tabular}

Despite the high number of I4.0 papers, only the ones with a high impact factor and recognized quartiles were considered to guarantee the reliability and validity of the information. We excluded all paper were not have a high impact factor and that 
not correspond to HPM project. Therefore, a total of 16 documents fulfilled the required criteria and were selected to this analysis. (see Table II).

\section{E. Methodological quality assessment}

After an evaluation based on inclusion and exclusion criteria, papers selected were evaluated in their quality through journal impact factor. Since WoS and Scopus databases do not show documents related to search strings to both I4.0 and HPM, Scopus is the only one left for the measurement. Hence, we assessed paper ranking according to $\mathrm{H}$ index, SJR and Q, where only papers with an impact factor greater than 2.0 and $\mathrm{H}$ index upper than 120 with a publication time not exceeding 5 years were used as a means of quality assessment, to guarantee the reliability of the information required to explain the study problem. Similar papers were evaluated in terms of content, methodology and contributions, where there was similarity, only the one with the greatest impact factor was considered.

\section{FINDING OF OUR REVIEWS}

\section{A. Overview of studies}

The 16 papers selected show that authors investigating issues associated with I4.0 and HPM have concentrated their publications on three journals, all evaluated as Q1, with impact factor upper than 2.1. For "Adaptability", we found two papers, "Reconfigurability" eight papers, "Customization" one paper, "Information systems" one paper and finally, one paper related to "Computed aided". Table III shows the distributions of studies according to publication channels.

TABLE III

PUBLICATION SOURCE

\begin{tabular}{|l|l|l|l|l|l|}
\hline Publication source & Type & Qty & $\begin{array}{l}\text { H } \\
\text { Index }\end{array}$ & Q & SJR \\
\hline $\begin{array}{l}\text { International Journal of } \\
\text { Production Economics }\end{array}$ & Journal & 13 & 155 & 1 & 2.4 \\
\hline $\begin{array}{l}\text { Supply Chain Management: } \\
\text { An international journal }\end{array}$ & Journal & 1 & 98 & 1 & 2.1 \\
\hline $\begin{array}{l}\text { International Journal of } \\
\text { Operations and Production } \\
\text { Management }\end{array}$ & Journal & 2 & 120 & 1 & 2.1 \\
\hline
\end{tabular}

Table IV shows objectives, questions and method used to measure relationship proposed for analyzed studies. Most of authors focused their statistics analysis on SEM and ANOVA method with the aim to achieved better measured of their models.

TABLE IV

Summary of Current TRend of Selected Hpm Literature RELATED WITH I4.0

\begin{tabular}{|l|l|l|}
\hline Citations & Goal / Questions & $\begin{array}{l}\text { Methodology } \\
\text { Measure }\end{array}$ \\
\hline $\begin{array}{l}\text { Alfalla-Luque R., } \\
\text { Machuca J.A.D., }\end{array}$ & $\begin{array}{l}\text { Determine whether SC agility, } \\
\text { alignment and adaptability have } \\
\text { Marin-Garcia }\end{array}$ & individual and/or joint effects \\
J.A., 2018 & SEM-PLS & \\
\hline
\end{tabular}

\begin{tabular}{|c|c|c|}
\hline Citations & Goal / Questions & $\begin{array}{l}\text { Methodology } \\
\text { Measure }\end{array}$ \\
\hline $\begin{array}{l}\text { Ye Y., Huo B., } \\
\text { Zhang M., Wang } \\
\text { B., Zhao X., } 2018\end{array}$ & $\begin{array}{l}\text { Measure the impacts of product } \\
\text { modularity (PM) and } \\
\text { multiskilled employees (MEs) } \\
\text { on new product development } \\
\text { (NPD) outcomes. }\end{array}$ & $\begin{array}{l}\text { Regression } \\
\text { model }\end{array}$ \\
\hline $\begin{array}{l}\text { Morita M., } \\
\text { Machuca J.A.D., } \\
\text { Flynn E.J., Pérez } \\
\text { De Los Ríos J.L., } \\
2015\end{array}$ & $\begin{array}{l}\text { Strengthen value chain's } \\
\text { creation capability. Examine } \\
\text { the relationship between } \\
\text { product characteristics and the } \\
\text { supply chain process. }\end{array}$ & $\begin{array}{l}\text { MANOVA } \\
\text { TEST / ANOVA } \\
\text { TEST }\end{array}$ \\
\hline $\begin{array}{l}\text { Li Ma, Xin Zhai, } \\
\text { Weiguo Zhong, } \\
\text { Zhi-Xue Zhang, } \\
2019 \\
\end{array}$ & $\begin{array}{l}\text { Formulate a strategy to } \\
\text { deploying human capital }\end{array}$ & $\begin{array}{l}\text { One-way } \\
\text { ANOVA, OLS }\end{array}$ \\
\hline $\begin{array}{l}\text { Ortega-Jimenez } \\
\text { C.H., Garrido- } \\
\text { Vega P., Cruz } \\
\text { Torres C.A., } 2020\end{array}$ & $\begin{array}{l}\text { To analyze whether } \\
\text { Reconfigurable Technologies } \\
\text { contribute to achieving Plant } \\
\text { Responsiveness (PR) and } \\
\text { whether this benefits from the } \\
\text { fit with Technology } \\
\text { Management and } \\
\text { Manufacturing Strategy, thus } \\
\text { forming a Strategic } \\
\text { Reconfigurable System (SRS). }\end{array}$ & $\begin{array}{l}\text { SEM, mediation } \\
\text { effect, CMB }\end{array}$ \\
\hline $\begin{array}{l}\text { Morita M., } \\
\text { Machuca J.A.D., } \\
\text { Pérez Díez de los } \\
\text { Ríos J.L., } 2018\end{array}$ & $\begin{array}{l}\text { The fit issue evaluated as the fit } \\
\text { between the product } \\
\text { development capability and the } \\
\text { supply chain capability }\end{array}$ & $\begin{array}{l}\text { ANOVA F } \\
\text { statistics, Simple } \\
\text { Regression } \\
\text { models }\end{array}$ \\
\hline $\begin{array}{l}\text { Huo B., Ye Y., } \\
\text { Zhao X., Zhu K., } \\
2019\end{array}$ & $\begin{array}{l}\text { To identify SCQI patterns and } \\
\text { investigate how they influence } \\
\text { quality-related performance }\end{array}$ & ANOVA \\
\hline $\begin{array}{l}\text { Arana-Solares } \\
\text { I.A., Ortega- } \\
\text { Jiménez C.H., } \\
\text { Alfalla-Luque R., } \\
\text { Pérez-Díez de los } \\
\text { Ríos J.L., } 2019\end{array}$ & $\begin{array}{l}\text { To explore whether either MS } \\
\text { or TM, or a combination of the } \\
\text { two, improves OP, and whether } \\
\text { contextual variables may also } \\
\text { influence OP. }\end{array}$ & $\begin{array}{l}\text { Regression } \\
\text { analysis, SEM }\end{array}$ \\
\hline $\begin{array}{l}\text { Wurzer T., Reiner } \\
\text { G., } 2018\end{array}$ & $\begin{array}{l}\text { To identify an improvement } \\
\text { practice that breaks with the } \\
\text { dilemma of choosing between } \\
\text { differentiation and cost } \\
\text { leadership }\end{array}$ & $\begin{array}{l}\text { SEM with } \\
\text { moderating effect }\end{array}$ \\
\hline $\begin{array}{l}\text { Sandrin E., } \\
\text { Trentin A., Forza } \\
\text { C., } 2018\end{array}$ & $\begin{array}{l}\text { To measure the impact of the } \\
\text { HI practices on MCC, Also, to } \\
\text { measure their impact for } \\
\text { different types of MC strategy, } \\
\text { characterized by different } \\
\text { values of DPC }\end{array}$ & $\begin{array}{l}\text { Multiple } \\
\text { regression } \\
\text { analysis, OLS, } \\
\text { MSEM }\end{array}$ \\
\hline $\begin{array}{l}\text { Zeng J., Zhang } \\
\text { W., Matsui Y., } \\
\text { Zhao X., } 2017\end{array}$ & $\begin{array}{l}\text { To study management practices } \\
\text { and their impact on plant } \\
\text { performance within global } \\
\text { competition. }\end{array}$ & SEM-CBS \\
\hline $\begin{array}{l}\text { Bortolotti T., } \\
\text { Boscari S., } \\
\text { Danese P., } 2015\end{array}$ & $\begin{array}{l}\text { To evaluate whether plants that } \\
\text { successfully implement LM are } \\
\text { characterized by a specific OC } \\
\text { profile. }\end{array}$ & $\begin{array}{l}\text { Multi-group } \\
\text { analysis method }\end{array}$ \\
\hline $\begin{array}{l}\text { Min Zhang, } \\
\text { Hangfei Guo, } \\
\text { Baofeng Huo, } \\
\text { Xiande Zhao, } \\
\text { Jianbo Huang, } \\
2019 \\
\end{array}$ & $\begin{array}{l}\text { To empirically investigate the } \\
\text { enabling roles of mass } \\
\text { customization and product } \\
\text { modularity in supply chain } \\
\text { quality integration }\end{array}$ & SEM-MLE \\
\hline
\end{tabular}




\begin{tabular}{|c|c|c|}
\hline Citations & Goal / Questions & $\begin{array}{l}\text { Methodology } \\
\text { Measure }\end{array}$ \\
\hline $\begin{array}{l}\text { Ortega Jimenez } \\
\text { C.H., Machuca } \\
\text { J.A.D., Garrido- } \\
\text { Vega P., Filippini } \\
\text { R., } 2015\end{array}$ & $\begin{array}{l}\text { To empirically show which } \\
\text { production programmed, } \\
\text { practices and linkages in } \\
\text { flexible environments should } \\
\text { be considered to support the } \\
\text { future adoption of practices } \\
\text { aimed at reconfigurability. }\end{array}$ & $\begin{array}{l}\text { Canonical } \\
\text { Correlation } \\
\text { Analyses }\end{array}$ \\
\hline $\begin{array}{l}\text { Garrido-Vega P., } \\
\text { Ortega Jimenez } \\
\text { C.H., De Los Ríos } \\
\text { J.L.D.P., Morita } \\
\text { M., 2015 }\end{array}$ & $\begin{array}{l}\text { To know if the plants need to } \\
\text { implement the same } \mathrm{S} \text { and } \mathrm{T} \\
\text { production practices regardless } \\
\text { of their industry and whether } \\
\text { these practices implementation } \\
\text { is the same in all industries. }\end{array}$ & $\begin{array}{l}\text { One-way } \\
\text { ANOVA, } \\
\text { Multiple } \\
\text { regression } \\
\text { analysis }\end{array}$ \\
\hline $\begin{array}{l}\text { Peng D.X., Liu } \\
\text { G.J., Heim G.R., } \\
2011\end{array}$ & $\begin{array}{l}\text { To examine the impact of IT on } \\
\text { MC capability rather than } \\
\text { manufacturing capabilities in } \\
\text { genera }\end{array}$ & SEM \\
\hline
\end{tabular}

All papers selected and shown in Table IV were developed on an empirical basis, combining interview, grounded theory, and reports. Central methods were survey, observation, study of cases and interview that permitting assessment the relationships, levels of dependence, mediation and moderation effect, and correlations. Table IV is the first evidence that research related to HPM has focused on the study of isolated practices and very little related to I4.0, without evidence of indepth studies of I.40 components in a way that allows the construction of a scale, they have only been studied through practices that contribute to performance and competitiveness, as well as the evaluation of technological inclusion. At the same time, it is shown that the articles are oriented to the evaluation of relationships using SEM and ANOVA methods in their majority. This allows reorienting HPM research in a specific field of I4.0. The following paragraphs correspond to answers to each research questions after a systematic literature review.

\section{B. Current trend in HPM}

Currently, most of papers in general literature are focus in analyzing issues such as: cyber physical production, smart manufacturing, smart factory, smart working, maintenance, capability development, aspect of risk management, digital manufacturing, revitalization of industry, implementation of I4.0, training around IoT and I4.0, quality improvement, Internet of things, socio technical challenges, block chain, supply chain, JIT, machine learning, safety process, text mining, assembly systems, waste reduction, smart products, IT infrastructure among others.

Trend of HPM project research related to industry 4.0, according to published empirical studies

HPM literature are focused in the last five years in topics such as adaptability, alignment, modularity, new product development, multiskilled employees, lead time, JIT, quality conformance, innovation, training, centralization, anticipation of new technologies, reconfigurability, integration, technology management, time, dependability, flexibility, reduction variability, product development capabilities, supply chain capability, improving quality, supply chain quality, supply chain performance, network, operational performance, manufacturing strategy, speed, customization, power, information, rewards, knowledge, quality information, process control, organization culture, Kanban, continuous flow, autonomous maintenance, customer involvement, lean manufacturing, operation management, high performance. supplier integration, internal quality integration, competitive performance, responsiveness, total quality, Product design, information technology, Product configurator IT, Manufacturing IT, new product development IT and supplier collaboration IT, etc. Principal finds of each papers analyzed are divided by keyword used in search string:

Adaptability. Product Modularity (PM) is positively related to New Product Development (NPD) outcomes and that Multi-skill employees do not have a significant impact. As we match modular designs and supply chain involvement to examine moderating effects, this suggest that Supplier Involvement and PM/MEs influence NPD outcomes synergistically, whereas Customer Involvement and MEs are substitutable. Besides, exist an independent effect of modular designs and existing evidence of positive impact of PM on NPD outcomes [23]. Manufacturing process and underlying technology are mature, and supply base is well-established in a stable supply chain. However, in an evolving supply chain, manufacturing process and underlying technology are still under early development and are rapidly changing. The paper introduces the concept of absolute supply chain orientation strategy (ASCOS) which focuses on perpetual improvements to lead-time, just-in-time control, quality and demand variability to ensure the fit between product characteristics and the supply chain process [16]. In general, and body of inquiry on deploying human capital in specific by demonstrating that across countries, task-related training is positively related to success of innovation. [25]

Reconfigurability. Plant Responsiveness (PR), can be measured as combination of time, dependability, and flexibility. Reconfigurable technologies (RT) are effective for achieving plant responsiveness (PR) when they are supported by Technology Management and Manufacturing Strategy, and by three programs forming what we have called a strategic reconfigurable system SRS. ASCOS concept is adopted in the present examination as it includes the main focuses of supply chain strategy determined in past research, such as lean, agility, and quality. However, as PDC and SCC are positively related to any of competitive measures, high PDC and SCC are desirable to prepare for any competitive situation. Looking at revolutionary industrial future driven by new emerging IT technologies and tools, it would be expected that strengthening both capabilities together could be an impending critical managerial agendum [25].

Customization. For instance, the delivery and flexibility, as service performance, can be greatly improved if supply chain processes are tightly coordinated, as can cost of quality. 
Findings of both Flynn et al. (2010) and this study reveal low and high uniform patterns, suggesting the existence of leading and lagging manufacturers about integration and quality integration, respectively [16]. On other hand, some studies have found that MS and TM practices together can lead to higher performance than when they are implemented individually. drawing on contingency theory, this paper tests whether relationship between MS and TM is affected by contextual factors in two industrial contexts (electronics and machinery sectors) [26].

At the same time, a positive relationship between MPD and cost performance, but do not show any moderating effects between MPD and delivery performance on flexibility performance and cost performance. Results of a correlation analysis between plant size and flexibility performance as well as cost performance were not significant [27]. Manufacturing environments with a high DPC, such as engineer-to-order environments, have become increasingly important to practice [28]. Hence, a simply upgrading technology and promoting these technical practices, which are also easy to be imitated and adopted by competitors, may not necessarily increase competitive advantage over time. Strong human resource utilization is required to identify and eliminate sources of quality problems effectively. Centralization of authority can facilitate implementation of hard QM it impedes implementation of soft QM [2]. Extensive use of hard practices and, by contrast, the lack of attention to soft practices can be results of some behavior's and attitudes, which are frequent in those companies which intend to implement lean but have not fully understood what this exactly means [29].

Other investigation shows that direct impact of mass customization on supplier quality integration is not significant. Mass customization aims to provide individually designed products to customers in a timely manner and at close to mass production prices, this enables a manufacturer to develop production capabilities in terms of quality, delivery, flexibility, and productivity. Product modularity allows functions to cooperate to solve conflict and quality problems by standardizing interfaces between modules, improving internal quality integration [30]. As well, Flexibility is seen as an inherent property of manufacturing systems that allows them to change within their own limitations (especially expected external changes) and reconfigurability is increasing technological responsiveness of production systems to not only foreseen, but also unforeseen events, such as sudden market changes or unexpected machine failures. [31]

Technology implementation. Other inquiry confirmed the existence of moderate interrelationships between $\mathrm{T}$ and $\mathrm{S}$ in all three sectors which could be qualified as reciprocal in terms of Thompson's (1967) typology for electronics and auto suppliers and sequential (from $T$ to $S$ ) in machinery. Although it appears that $\mathrm{T}$ has a greater influence on $\mathrm{S}$, than $\mathrm{S}$ does on $\mathrm{T}$ in all sectors, the difference was greatest in machinery. Meanwhile, Toyota emphasizes "avoidance of waste" or "lean" and then develops a JIT system and relevant technologies, such as set-up time reduction technologies and quality-related technologies. In any case, any firm that has a clear competitive focus establishes its production strategy (representing the emphasis on competitive focuses) and tries to develop or install technologies that contribute to focuses. These firms accept under their clear competitive focuses new technologies that have been examined and developed and implement them. Sometimes this strengthens, or makes it possible to feature, new competitive focuses that had been considered difficult [32].

IT: Computer aided engineering. Various types of IT help a firm to process information fast, accurately, and inexpensively. Therefore, IT applications can increase a firm's information processing capabilities that are required to carry out MC. As a result, IT applications facilitate a firm's MC capability. Future inquiry can also benefit from this theory in investigating the role of IT applications in a MC system. However, the effect of manufacturing IT on MC capability is found insignificant. Modular product design relates positively to configurator IT usage. Studies reinforce findings in prior literature using IT for product design and manufacturing enhances a firm's MC capability [33].

C. Variables that have been used in HPM project research to evaluate technology inclusion, internet of things, cloud computing, cyber physical systems, adaptability, flexibility, time, performance, and integration such as previous elements of industry 4.0 in manufacturing

Table V. shows variables that authors used to explain cross-sectional inclusion of technology in manufacturing processes, highlighting that these are oriented to customization, Modularity, Adaptability, Reconfigurability, Information Systems, Responsiveness, ASCO, JIT, Innovation and Anticipation of new technology. Variables formed series of constructs that were evaluated on Likert scales (levels 1 to 7).

TABLE V

HPM VARIABLES AND THEIR RELATIONSHIP WITH I4.0 VARIABLES

\begin{tabular}{|c|c|c|}
\hline Citations & Variables / Scales HPM & $\begin{array}{l}\text { Relationship } \\
\text { with I4.0 }\end{array}$ \\
\hline $\begin{array}{l}\text { Alfalla-Luque } \\
\text { R., Machuca } \\
\text { J.A.D., Marin- } \\
\text { Garcia J.A., } \\
2018 \\
\end{array}$ & $\begin{array}{l}\text { Supply chain: agility, } \\
\text { Adaptability and Alignment }\end{array}$ & $\begin{array}{l}\text { Agility and } \\
\text { flexibility, one } \\
\text { of principles of } \\
\text { I4 }\end{array}$ \\
\hline $\begin{array}{l}\text { Ye Y., Huo B., } \\
\text { Zhang M., Wang } \\
\text { B., Zhao X., } \\
2018\end{array}$ & $\begin{array}{l}\text { New product development, } \\
\text { Product modularity, } \\
\text { Multiskilled employees }\end{array}$ & $\begin{array}{l}\text { Modularity, one } \\
\text { of principles of } \\
\text { I4.0 }\end{array}$ \\
\hline $\begin{array}{l}\text { Morita M., } \\
\text { Machuca J.A.D., } \\
\text { Flynn E.J., Pérez } \\
\text { De Los Ríos } \\
\text { J.L., } 2015\end{array}$ & $\begin{array}{l}\text { Shorter lead-time focus (SLT), } \\
\text { JIT focus, Quality, especially } \\
\text { quality conformance, focus } \\
\text { (QFS), Increasing demand } \\
\text { stability focus (SFS) }\end{array}$ & $\begin{array}{l}\text { Agility, } \\
\text { Capabilities, JIT, } \\
\text { lean } \\
\text { manufacturing } \\
\text { along industry } \\
4.0 \text {, quality, } \\
\text { delivery, } \\
\text { flexibility, FIT }\end{array}$ \\
\hline $\begin{array}{l}\text { Li Ma, Xin Zhai, } \\
\text { Weiguo Zhong, } \\
\text { Zhi-Xue Zhang, } \\
2019\end{array}$ & $\begin{array}{l}\text { Firm innovation, New product } \\
\text { development, task related } \\
\text { training, centralization, control } \\
\text { level economy growth }\end{array}$ & $\begin{array}{l}\text { Innovation, } \\
\text { Centralization, } \\
\text { Human } \\
\text { intervention, } \\
\text { human aspect }\end{array}$ \\
\hline
\end{tabular}




\begin{tabular}{|c|c|c|}
\hline Citations & Variables / Scales HPM & $\begin{array}{l}\text { Relationship } \\
\text { with I4.0 }\end{array}$ \\
\hline $\begin{array}{l}\text { Ortega-Jimenez } \\
\text { C.H., Garrido- } \\
\text { Vega P., Cruz } \\
\text { Torres C.A., } \\
2020\end{array}$ & $\begin{array}{l}\text { PR (time, dependability, and } \\
\text { flexibility), Modularization, } \\
\text { Anticipation of new } \\
\text { technologies, Technology } \\
\text { management, reconfigurable } \\
\text { technology, SC integration, SC } \\
\text { human support. }\end{array}$ & $\begin{array}{l}\mathrm{CNC}, \\
\text { Reconfigurabilit } \\
\mathrm{y} \text {, flexibility, } \\
\text { reconfigurability } \\
\text { production } \\
\text { technology }\end{array}$ \\
\hline $\begin{array}{l}\text { Morita M., } \\
\text { Machuca J.A.D., } \\
\text { Pérez Díez de } \\
\text { los Ríos J.L., } \\
2018\end{array}$ & $\begin{array}{l}\text { ASCOS: lean time reduction, } \\
\text { just in time, improving quality, } \\
\text { reduction of demand } \\
\text { variability. Product } \\
\text { development capabilities, } \\
\text { Supply chain capability }\end{array}$ & $\begin{array}{l}\text { Technology } \\
\text { decision, } \\
\text { technology risk, } \\
\text { capability, agile }\end{array}$ \\
\hline $\begin{array}{l}\text { Huo B., Ye Y., } \\
\text { Zhao X., Zhu K., } \\
2019\end{array}$ & $\begin{array}{l}\text { Quality management, supply } \\
\text { chain quality management, } \\
\text { quality performance, supply } \\
\text { chain network, supply chain } \\
\text { integration }\end{array}$ & $\begin{array}{l}\text { Technology } \\
\text { improvement, } \\
\text { integration, } \\
\text { Supply chain } \\
\text { integration, } \\
\text { quality } \\
\text { information }\end{array}$ \\
\hline $\begin{array}{l}\text { Arana-Solares } \\
\text { I.A., Ortega- } \\
\text { Jiménez C.H., } \\
\text { Alfalla-Luque } \\
\text { R., Pérez-Díez } \\
\text { de los Ríos J.L., } \\
2019 \\
\end{array}$ & $\begin{array}{l}\text { Plant size, environmental } \\
\text { complexity, plant focus, plant } \\
\text { description, operational } \\
\text { performance, technology } \\
\text { management, manufacturing } \\
\text { strategy. }\end{array}$ & $\begin{array}{l}\text { Modularity, new } \\
\text { technology, } \\
\text { capability, } \\
\text { product design }\end{array}$ \\
\hline $\begin{array}{l}\text { Wurzer T., } \\
\text { Reiner G., } 2018\end{array}$ & $\begin{array}{l}\text { Modularization of products, } \\
\text { Ability to Meet Customers' } \\
\text { Speed Needs, quality, delivery, } \\
\text { flexibility }\end{array}$ & $\begin{array}{l}\text { Modularity, } \\
\text { flexibility } \\
\text { performance }\end{array}$ \\
\hline $\begin{array}{l}\text { Sandrin E., } \\
\text { Trentin A., } \\
\text { Forza C., } 2018\end{array}$ & $\begin{array}{l}\text { Mass-customization capability, } \\
\text { four PIRK-HI (power HI, } \\
\text { Information HI, Rewards HI, } \\
\text { Knowledge HI) Degree of } \\
\text { product customization }\end{array}$ & $\begin{array}{l}\text { Customization, } \\
\text { capability, } \\
\text { Modularity, }\end{array}$ \\
\hline $\begin{array}{l}\text { Zeng J., Zhang } \\
\text { W., Matsui Y., } \\
\text { Zhao X., } 2017\end{array}$ & $\begin{array}{l}\text { Quality information, process } \\
\text { management, Small group } \\
\text { problem solving, employee } \\
\text { suggestion, and task-related } \\
\text { training for employees, } \\
\text { process control, preventive } \\
\text { maintenance, and } \\
\text { housekeeping }\end{array}$ & $\begin{array}{l}\text { Optimization, } \\
\text { data analysis, } \\
\text { human aspect, } \\
\text { technical } \\
\text { assistant }\end{array}$ \\
\hline $\begin{array}{l}\text { Bortolotti T., } \\
\text { Boscari S., } \\
\text { Danese P., } 2015\end{array}$ & $\begin{array}{l}\text { Lean manufacturing, } \\
\text { Organizational culture, JIT, } \\
\text { Operation management, } \\
\text { Continuous flow, Kanban, } \\
\text { autonomous maintenance, } \\
\text { customer involvement, } \\
\text { continuous improvement }\end{array}$ & $\begin{array}{l}\text { Manufacturing } \\
\text { technology, New } \\
\text { technology, JIT, } \\
\text { Kanban, deliver, } \\
\text { pull systems, } \\
\text { equipment, } \\
\text { Human aspect } \\
\end{array}$ \\
\hline $\begin{array}{l}\text { Min Zhang, } \\
\text { Hangfei Guo, } \\
\text { Baofeng Huo, } \\
\text { Xiande Zhao, } \\
\text { Jianbo Huang, } \\
2019\end{array}$ & $\begin{array}{l}\text { Mass customization, Supplier } \\
\text { quality integration, Internal } \\
\text { quality integration, Customer } \\
\text { quality integration, Product } \\
\text { modularity, Competitive } \\
\text { performance }\end{array}$ & $\begin{array}{l}\text { Information } \\
\text { technology, } \\
\text { operational } \\
\text { decision, } \\
\text { manufacturing } \\
\text { technology, } \\
\text { integration, } \\
\text { production } \\
\text { capability }\end{array}$ \\
\hline $\begin{array}{l}\text { Ortega Jimenez } \\
\text { C.H., Machuca } \\
\text { J.A.D., Garrido- } \\
\text { Vega P., } \\
\text { Filippini R., } \\
2015\end{array}$ & $\begin{array}{l}\text { Cost, Quality, Responsiveness } \\
\text { (speed, time, dependability, } \\
\text { adjustability) Production } \\
\text { strategy (PS), just-in-time } \\
\text { (JIT), production technology } \\
\text { (T), total quality (TQ), human } \\
\text { resources (HR) and total }\end{array}$ & $\begin{array}{l}\text { JIT, TPM, TQ, } \\
\text { HR, PS, product } \\
\text { design } \\
\text { simplicity, } \\
\text { willingness to } \\
\text { introduce new } \\
\text { technology and }\end{array}$ \\
\hline
\end{tabular}

\begin{tabular}{|c|c|c|}
\hline Citations & Variables / Scales HPM & $\begin{array}{l}\text { Relationship } \\
\text { with I4.0 }\end{array}$ \\
\hline & $\begin{array}{l}\text { productive maintenance } \\
\text { (TPM) }\end{array}$ & $\begin{array}{l}\text { CAD/CAM/CIM } \\
/ \text { FMS/CNC }\end{array}$ \\
\hline $\begin{array}{l}\text { Garrido-Vega P., } \\
\text { Ortega Jimenez } \\
\text { C.H., De Los } \\
\text { Ríos J.L.D.P., } \\
\text { Morita M., 2015 }\end{array}$ & $\begin{array}{l}\text { Production strategy, } \\
\text { Technology, Effective process } \\
\text { implementation, } \\
\text { Interfunctional design efforts, } \\
\text { New product introduction, } \\
\text { Supplier involvement, } \\
\text { Performance, Formal strategic } \\
\text { Planning, Anticipation of new } \\
\text { technology, communication of } \\
\text { manufacturing strategy, } \\
\text { manufacturing business } \\
\text { strategy linkage }\end{array}$ & $\begin{array}{l}\text { Information } \\
\text { technology, data, } \\
\text { technology, } \\
\text { machine } \\
\text { learning, } \\
\text { integration, } \\
\text { customization }\end{array}$ \\
\hline $\begin{array}{l}\text { Peng D.X., Liu } \\
\text { G.J., Heim G.R., } \\
2011\end{array}$ & $\begin{array}{l}\text { Information Technology, Mass } \\
\text { customization capability: } \\
\text { product configurator IT, new } \\
\text { product development IT, } \\
\text { manufacturing IT, supplier } \\
\text { collaboration IT }\end{array}$ & $\begin{array}{l}\text { Modular, } \\
\text { product design, } \\
\text { Manufacturing } \\
\text { IT, Information } \\
\text { Technology, } \\
\text { Capability }\end{array}$ \\
\hline
\end{tabular}

Results of Table V shows that in current HPM literature, studies have focused on disaggregated elements that are part of I4.0 but it is lacking of studies that assesses maturity level and infrastructure of I4.0 through scales like: connectivity, automation, network, CPS, cloud computing. Further, this inquiry has been associated with the principles that govern I4.0 as the basis for CPS establishment and other components. Most of investigations have focused on horizontal integration analysis, few in vertical integration.

\section{Future scope for further research of HPM project related with industry 4.0}

Even though, aspects related to I4.0 along the time have been dealt with manufacturing practices, there are many spaces for continuous examination since the same I4.0 concept and its key indicators of continue measurement in study for their consolidation. As regard horizontal integration the future scope is associated with integration of various IT systems used in different stages of manufacturing and business planning processes within a company (e.g. inbound logistics, production, outbound logistics, marketing) and between several different companies (value networks). With respect vertical integration the future scope is associated with integration of various IT systems at different hierarchical levels (e.g. actuator and sensor level, manufacturing and execution level, production management level, and corporate planning levels) to deliver an end-to-end solution. End-to-End Digital Integration: integration throughout engineering process so that digital and real worlds are integrated across a product's entire value chain and across different companies, whilst incorporating customer requirements. Likewise the company's should be focused on standardization, reference architecture, managing complex systems, Delivering, Safety and Security, Work organization 
and design, Training, Regulatory framework, Resource productivity and efficiency [34] Specifically, complement and restructure scales including in a transversal way the degree of implementation, current status and the level of use of components of I4.0. (CPS, IoT, Cloud Computing, Data, etc.)

Moreover, another future scope it is related to security, where the risks from IT are affecting the industrial manufacturing process and we need to counteract new potential manufacturing industrial risks, not only in all related with systems but also in human capital [14].

Its necessary rethink some scales of HPM project combining them under I4.0 scale. Research fields should assess adaptability, timing, flexibility, modularity, quality, waste, performance, depending on the level of maturity and infrastructure of I4.0. Also, it required of more investigation related to data science, such as real time data analysis, data integration, blockchain and big data analytics. The upgrade of existing technologies, such as Programmable Logic Controllers, Production Machinery, and Industrial Robots, to meet needs of I4.0. Moreover, study efforts have been dedicated to support the management of production systems related to I4.0 area, with continuous investigation about strategic management, decision-making, location tracking, reconfigurability and sustainability

\section{CONCLUSIONS}

The papers analyzed and associated with HPM project that study issues related to I4.0 do not show evidence of a holistic evaluation of principles and foundations that make up I4.0. They do not have a defined scale, or variables that measured I4.0 components. Besides, while current trend for I.4.o in in the HPM context is the study of adaptability, flexibility, reconfigurability, new information technologies, modularity, automation among others, they do not address topics about CPS, Internet of things and cloud computing, thus making difficult the construction of a definition of I4.0 in this context. Further, the HPM Project has evaluated in a disaggregated way a series of elements related to I4.0 that conform its practices and scales. Since the $80^{\prime}$ s there is a concern to constantly evaluate how industrial revolution [4] and the entry of internet, technological and knowledge advances, change the way of managing manufacturing processes, adjusting every day its entire chain to the needs of its consumers and companies requiring that its suppliers adjust to their processes. All above are stimulated by the pressures to improve performance of companies, with the best use of resources, less waste and errors and disagreements at lowest possible cost for their companies. Industry 4.0 is moving international projects towards the study of inclusion of ICT in their processes. IoT demands that there be an effort to realize studies that analyze the passage from one revolution to another (III to IV revolution) since studies support that competitive performance of organizations every day will pass through inclusion of CPS, IoT, Data analysis and cloud computing, networking, etc.
The focus of this paper was consolidated the existing knowledge on I4.0 and HPM, providing a starting point for academics and practitioners seeking to implement I4.0 in plants, offering suggestions for future investigation. Limitations related to the research design present an opportunity for future examination. One limitation is associated with literature review, because this paper only includes journal articles related to I4.0 from the HPM project research. Since only about $10 \%$ of I 4.0 papers found came from the HPM project, an scope for future investigation may be to consider conference proceeding and other papers outside the HPM project, to confirm and expand results and determine a more robust current state of knowledge and build a consensus definition. Hence, it is necessary develop additional study about; infrastructure status for I4.0 implementation, machinery automation levels, socio-technical aspects of I4.0 implementation, competitive advantages, and migration strategies from I3.0 to I4.0. Results of these studies will contribute to build, assess, and establish new scales for the next round of the HPM project. At the same time, cultural factors are still being ignored, these being transcendental for changes that require less human presence and more automation, machine learning, network, CPS, etc. Regarding the challenges, it is important to mention that due to levels of inclusion of I4.0 in countries that are part of the project, there will be aspects that cannot be evaluated from I4.0 perspective but can be evaluate from current aspects of manufacturing practices.

However, it is evident that I4.0 is a critical factor for reduce manufacturing costs and waste and HPM success, and its impact will be subject of future research to determine what are the I4.0 practices more conducive to higher HPM [40]. There is also a need to develop a new model of I4.0 that encompasses I4.0 practices needed for HPM and readjusted the present practices.

\section{ACKNOWLEDGMENT}

This research has been partly funded by the Spanish Ministry of Science and Innovation, Project DPI-2009-11148, and by the Junta de Andalucía Project P08-SEJ-03841. The authors wish to acknowledge the support afforded by the Spanish and Andalusian Governments.

\section{REFERENCES}

[1] Acevedo Amaya, M. R., Ortega Jiménez, C. H., Domínguez Machuca, J. A., \& Alfalla Luque, R.. Modelos bivariados de ajuste de la relación producción lean-gestión de cadena de suministros sobre el rendimiento competitivo: un efecto interviniente e interactivo. LACCEI, 2019.

[2] Zeng, J., Zhang, W., Matsui, Y., \& Zhao, X., The impact of organizational context on hard and soft quality management and innovation performance. International Journal of Production Economics, vol. 185(1), pp. 240-251, 2017.

[3] Acevedo Amaya, M. R., Ortega Jiménez, C. H., Domínguez Machuca, J. A., \& Alfalla Luque, R., Las evidencias de mediación de los programas de lean en la cadena de suministros y el rendimiento competitive de las operaciones de las empresas bajo producción de alto rendimiento. LACCEI, 2018.

[4] Feng, Q., \& Shanthikumar, J. G., How Research Production and Operations Management May Evolve in the Era of Big Data. Production and Operations Management, vol. 27(9), pp. 1670-1684, 2018. 
[5] Osterrieder, P., Budde, L., \& Friedli, T., The smart factory as a key construct of industry 4.0: A systematic literature review. International Journal of Production Economics, pp. 1-16, 2019.

[6] Castelo-Branco, I., Cruz-Jesus, F., \& Oliveira, T., Assessing Industry 4.0 readiness in manufacturing: Evidence for the European Union. Computers in Industry, vol. 107, pp. 22-32, 2019.

[7] Ebrahimi, M., Baboli, A., \& Rother, E., The evolution of world class manufacturing toward Industry 4.0: a case study in the automotive industry. IFAC, vol. 52(10), pp. 188-194, 2019.

[8] Sisinni, E., Saifullah, A., Han, S., Jennehag, U., \& Gidlund, M. Industrial internet of things: Challenges, opportunities, and directions. IEEE TRANSACTIONS ON INDUSTRIAL INFORMATICS, vol. 14(11), pp. 4724-4734, 2019.

[9] Xu, L. D., Xu, E. L., \& Li, L., Industry 4.0: State of the art and future trends. International Journal of Production Research, vol. 56(8), pp. 2941-2962, 2018.

[10]Frank, A. G., Dalenogare, L. S., \& Ayala, N. F., Industry 4.0 technologies: Implementation patterns in manufacturing companies. International Journal of Production Economics, vol. 210, pp. 15-26, 2019.

[11]Dalenogare, L. S., Benitez, G. B., Ayala, N. F., \& Frank, A. G., The expected contribution of industry 4.0 technologies for industrial performance. International Journal of Production Economics, vol. 204(1), pp. 383-394, 2018.

[12]Raj, A., Dwivedi, G., Sharma, A., Jabbour, A. B., \& Rajak, S., Barriers to the adoption of industry 4.0 technologies in the manufacturing sector: An inter-country comparative perspective. International Journal of Production Economics, pp. 1-18, 2019

[13]Fettermann, D. C., Cavalcante, C. G., Almeida, T. D., \& Tortorella, G. L., How does Industry 4.0 contribute to operations management? Journal of Industrial and Production engineering, pp. 1-14, 2018.

[14]Monostori, L., Bauernhansl, T., Kádár, B., \& Kondoh, S. Cyber-physical systems in manufacturing. CIRP Annals Manufacturing technology, pp. 622-642, 2016.

[15]Tupa, J., Simota, J., \& Steiner, F., Aspects of risk management implementation for Industry 4.0. Procedia Manufacturing, Vol. 11, 12231230, 2017.

[16]Flynn, B., Schroeder, R., Flynn, E., Sakakibara, S. and Bates, K., Worldclass manufacturing project: overview and selected results, International Journal of Operations \& Production Management, Vol. 17 No. 7, pp. 671$685,1997$.

[17]Forza, C., \& Salvador, F., Information flows for high-performance manufacturing. International Journal of Production Economics, vol. 70(1), pp. 21-36, 2001.

[18]Morita, M., Machuca, J. A., Flynn, E. J., \& Ríos, J. L. Aligning product characteristics and the supply chain process - A normative perspective. International Journal of Production Economics, vol. 161(1), pp. 228-241, 2015.

[19]Huo, B., Ye, Y., Zhao, X., \& Zhu, K., Supply chain quality integration: A taxonomy perspective. International Journal of Production Economics, vol. 207, pp. 236-246, 2019.

[20]Sandengen, O. C., \& Leif A. Estensen, H. R., High Performance Manufacturing - An Innovative Contribution towards Industry 4.0. International Workshop of Advanced Manufacturing and Automation (IWAMA 2016) pp. 1-7. Manchester, UK: Atlantis Press, 2016.

[21]Vaidyaa, S., Ambad, P., \& Bhosle, S., Industry 4.0 - A Glimpse. Procedia Manufacturing, vol. 20(1), pp. 233-238, 2018.

[22]Liao, Y., Deschamps, F., Loures, E. d., \& Ramos, L. F., Past, present and future of Industry 4.0 - a systematic literature review and research agenda proposal. International Journal of Production Research, vol. 55(12), pp. 119, 2017.

[23]Inayat, I., Salim, S. S., Marczak, S., Daneva, M., \& Shamshirband, S., A systematic literature review on agile requirements engineering practices and challenges. Computers in human behavior, 51, 915-929, 2015.

[24]Xiao, Y., \& Watson, M., Guidance on Conducting a Systematic Literature Review. Journal of Planning Education and Research, vol. 39(1), pp. 93$112,2017$.

[25]Inayat, I., Salim, S. S., Marczak, S., Daneva, M., \& Shamshirband, S., A systematic literature review on agile requirements engineering practices and challenges. Computers in Human Behavior, vol. 51(1), pp. 915-929, 2015.

[26]Ye, Y., Huo, B., Zhang, M., Wang, B., \& Zhao, X., The impact of modular designs on new product development outcomes: the moderating effect of supply chain involvement. Supply Chain Management, vol. 23(5), pp. 444458, 2018.

[27]Ma, L., Zhai, X., Zhong, W., \& Zhang, Z.-X., Deploying human capital for innovation: A study of multi-country manufacturing firms. International Journal of Production Economics, vol. 208(1), pp. 241-253, 2019.

[28]Morita, M., Machuca, J. A., \& Ríos, J. L., Integration of product development capability and supply chain capability: The driver for high performance adaptation. International Journal of Production Economics, vol. 200(1), pp. 68-82, 2018.

[29]Arana-Solares, I. A., Ortega-Jiménez, C. H., Alfalla-Luque, R., \& Ríos, J. L.-D. Contextual factors intervening in the manufacturing strategy and technology management-performance relationship. International Journal of Production Economics, vol. 207, pp. 81-95, 2019.

[30]Wurzer, T., \& Reiner, G., Evaluating the impact of modular product design on flexibility performance and cost performance with delivery performance as a moderator. International Journal of Operations \& Production Management, vol. 38(10), pp. 1987-2008, 2018.

[31]Sandrin, E., Trentin, A., \& Forza, C., Leveraging high-involvement practices to develop mass customization capability: A contingent configurational perspective. International Journal of Production Economics, vol. 196(1), pp. 335-345, 2018.

[32]Bortolotti, T., Boscari, S., \& Danese, P., Successful lean implementation: Organizational culture and soft lean practices. International Journal of Production Economics, vol. 160, pp. 182-201, 2015.

[33]Zhang, M., Guo, H., Huo, B., Zhao, X., \& Huang, J., Linking supply chain quality integration with mass customization and product modularity. International Journal of Production Economics, vol. 207, pp. 227-235, 2019.

[34]Garrido-Vega, P., Ortega-Jimenez, C. H., Ríos, J. L., \& Morita, M., Implementation of technology and production strategy practices: Relationship levels in different industries. International Journal of Production Economics, vol. 161, pp. 201-216, 2015.

[35]Ortega-Jimenez, C. H., Machuca, J. A., Garrido-Vega, P., \& Filippini, R., The pursuit of responsiveness in production environments: From flexibility to reconfigurability. International Journal of Production Economics, vol. 163, pp. 157-172, 2015.

[36]Peng, D. X., Liu, G.., \& Heim, G. R., Impacts of information technology on mass customization capability of manufacturing plants. International Journal of Operations \& Production Management, vol. 31(10), pp. 10221047, 2011.

[37]Liao, Y., Deschamps, F., Loures, E. d., \& Ramos, L. F., Past, present and future of Industry 4.0 - a systematic literature review and research agenda proposal. International Journal of Production Research, pp. 1-22, 2017.

[38] Ortega-Jimenez, C. H., Garrido-Vega, P., \& Torres, C. A., Achieving plant responsiveness from reconfigurable technology: Intervening role of SCM. International Journal of Production Economics, vol. 219, pp. 195-203, 2020.

[39]Sony, M., \& Naik, S., Key ingredients for evaluating industry 4.0 readiness for organization's: a literature review. Benchmarking: an international Journal, pp. 1-23, 2018

[40]Acevedo Amaya, M. R., Ortega-Jiménez, C. H., \& Alfalla-Luque, R. Mediation Effect of Lean: A Bidirectional Synergetic Relationship with SCM for Higher Operational Performance. The Journal of Japanese Operations Management and Strategy, vol. 8, No. 1, pp. 51-66, 2018 